\title{
Liver Cancer pT3b TNM Finding v7
}

National Cancer Institute

\section{Source}

National Cancer Institute. Liver Cancer pT3b TNM Finding v7. NCI Thesaurus. Code C90162.

Liver cancer with single tumor or multiple tumors of any size involving a major branch of the portal vein or hepatic vein. (from AJCC 7th Ed.) 